\title{
Efektifitas Beberapa Tanaman dalam Mengendalikan Lalat Rumah (Musca domestica)
}

\section{The Effectiveness of Several Plants in Controlling House Flies (Musca domestica)}

\author{
Mei Ahyanti ${ }^{1}$, Prayudhy Yushananta ${ }^{2}$, Sarip Usman ${ }^{3}$ \\ ${ }^{1}$ Politeknik Kesehatan Kemenkes Tanjungkarang, Indonesia \\ (email : mei.ahyanti@gmail.com,no.telepon/Hp : 08127222587)
}

\begin{abstract}
ABSTRAK
WHO menyatakan diare sebagai ancaman kesehatan. Di Indonesia, hingga saat ini diare masih menjadi masalah kesehatan masyarakat. Prevalensi diare di Provinsi Lampung tahun 2018 sebesar 4,51\% menyebar di setiap kabupaten / kota. Peningkatan penyakit diare terjadi karena mengkonsumsi makanan yang tercemar oleh mikroorganisme melalui perantara lalat. Hingga saat ini belum ada penelitian yang dilakukan untuk menguji efektifitas berbagai tanaman dalam mengendalikan lalat rumah (Musca domestica). Penelitian bertujuan mendapatkan bahan aktif potensial sebagai bioinsectisida berbasis tanaman dan membuktikan bahwa bahan aktif pada tanaman dapat digunakan sebagai bioinsectisida untuk mengendalikan lalat. Tahapannya adalah ekploring bahan aktif pada tanaman, penentuan tanaman dengan kandungan bahan aktif tertinggi, dan uji coba ektrak tanaman terhadap mortalitas lalat. Penelitian ini merupakan eksperimen dengan rancangan faktorial. Variabel yang dikaji adalah konsentrasi dan waktu kontak terhadap kematian lalat dengan dua kali pengulangan. Penelitian ini menemukan tanaman yang efektif sebagai bioinsectisida dalam mengendalikan lalat rumah (Musca domestica) adalah daun pepaya.
\end{abstract}

Kata kunci : Bioinsectisida, Efektif, Lalat Rumah, Tanaman Daun Pepaya

\section{ABSTRACT}

WHO declares diarrhea a health threat. In Indonesia, diarrhea is still a public health problem. The prevalence of diarrhea in Lampung Province in 2018 was $4.51 \%$ spread in every district / city. The increase in diarrheal disease occurs due to consuming food contaminated by microorganisms through the intermediary of flies. Until now there has been no research conducted to test the effectiveness of various plants in controlling houseflies (Musca domestica). The aim of the study was to obtain potential active ingredients as plant-based bioinsecticides and to prove that the active ingredients in plants can be used as bioinsecticides to control flies. The stages are exploring the active ingredients in plants, determining the plants with the highest content of active ingredients, and testing plant extracts on fly mortality.This research is an experiment with a factorial design. The variables studied were concentration and contact time on fly mortality with two repetitions. This study found that the plant that is effective as a bioinsecticide in controlling the house fly (Musca domestica) is papaya leaf.

\section{Keywords : Bioinsecticide, Effective, House Flies, Papaya Leaf Plant}

https://doi.org/10.33860/jik.v15i4.757

(C) 2021 by the authors. Submitted for possible open access publication under the terms and conditions of the Creative Commons Attribution (CC BY SA) license (https://creativecommons.org/licenses/by-sa/4.0/).

\section{PENDAHULUAN}

Sanitasi memiliki peran besar dalam kejadian diare dan menjadi salah satu tantangan bagi negara berkembang. World Health Organization (WHO) menyatakan diare sebagai ancaman kesehatan. Di Indonesia, hingga saat ini diare masih menjadi masalah kesehatan masyarakat. Prevalensi diare di Provinsi Lampung tahun 2018 sebesar 4,51\% menyebar di setiap kabupaten / kota (1). Cakupan pelayanan diare baru mencapai 59,39\% padahal target tahun 2019 adalah $100 \%{ }^{(2)}$. Berdasarkan 
data Dinas Kesehatan Kota Bandar Lampung tahun 2020, secara umum trend kejadian diare pada semua umur di Kota Bandar Lampung tahun 2017-2020 cenderung fluktuatif. Peningkatan penyakit diare dapat terjadi karena mengkonsumsi makanan yang tercemar. Penelitian Laseri (2017) mendapatkan kondisi tempat penyimpanan makanan yang dijual lingkungan sekolah di Kota Bandar Lampung dibiarkan terbuka, hal ini menyebabkan makanan terkotaminasi mikroorganisme melalui perantara vektor lalat ${ }^{(3)}$. Dari hasil analisis laboratorium diduga penyebab diare pada balita di puskesmas Kedaton Kota Bandar Lampung disebabkan oleh bakteri yang mencemari makanan ${ }^{(4)}$.

Masalah sampah sebagai akibat dari pertambahan penduduk memberikan dampak negatif berupa tingginya kepadatan lalat. Ancaman lalat yang datang dan kontak dengan manusia berdampak penularan penyakit. Peranan lalat dalam penularan penyakit pada umumnya bersifat mekanis yaitu lalat yang hinggap pada kotoran, kotoran menempel pada kaki lalat dan hinggap pada makanan sehingga makanan tersebut terkontaminasi. Pada akhirnya lalat akan menimbulkan masalah kesehatan masyarakat secara luas baik dari segi estetika sampai penularan penyakit. Lalat yang umum dijumpai dilingkungan permukiman adalah lalat rumah (Musca domestica). Serangga ini berkembang biak dengan cepat, umumnya hinggap di kotoran manusia dan hewan serta bahan organik lainnya seperti daging, buah, ikan, dan tumbuhan segar maupun yang sudah membusuk ${ }^{(5)}$. Masyarakat telah melakukan upaya pengendalian lalat rumah menggunakan insektisida kimia.

Penggunaan insektisida kimia untuk mengendalikan lalat mempunyai efek yang membahayakan bagi serangga non target, serta ikut terpaparnya manusia dan lingkungan. Oleh karena itu, perlu dicari insektisida nabati sebagai salah satu alternatif penggantinya. Insektisida nabati merupakan kelompok insektisida yang berasal dari tanaman, seperti piretrum, piretrin, nikoton, rotenon, limonen, azadirachtin, dan lain-lain. Penggunaan insektisida nabati, selain membantu menurunkan populasi lalat juga aman bagi manusia dan lingkungan ${ }^{(6)}$.

Penggunaan insektisida alami perlu dikembangkan, karena Indonesia kaya berbagai jenis tumbuhan yang dapat dimanfaatkan sebagai insektisida alami ${ }^{(7)}$. Senyawa yang terkandung dalam pestisida berbahan alami dari lingkungan memiliki kelebihan dibandingkan pestisida sintetik. Dalam suatu ekstrak tumbuhan, terdapat beberapa senyawa utama yang aktif dan senyawa lain yang kurang aktif. Keberadaa senyawa yang kurang aktif dapat bersinergi dan memicu aktivitas esktrak secara keseluruhan. Beberapa tumbuhan berpotensi sebagai insectisida karena mengandung beberapa senyawa bioaktif, seperti saponin, flavonoid, alkaloid, tanin, dan alkenil fenol. Hingga saat ini belum banyak penelitian yang mengkaji tentang pengaruh berbagai jenis tanaman dalam mengendalikan lalat rumah (Musca domestica). Penelitian ini bertujuan memperoleh tanaman yang efektif dalam mengendalikan lalat rumah (Musca domestica).

\section{METODE PENELITIAN}

Penelitian ini adalah penelitian eksperimen menggunakan rancangan faktorial. Penelitian diawali perkembangbiakan lalat, melakukan ekstraksi tanaman dan mengukur kandungan zat aktif. Selanjutnya dilakukan uji coba ekstrak tanaman terhadap mortalitas lalat rumah (Musca domestica) Variabel yang di teliti adalah konsentrasi dan lama kontak terhadap kematian lalat rumah (Musca domestica). Variasi perlakuan adalah sebanyak 5 konsentrasi $(25 \%, 30 \%, 35 \%, 40 \%$ dan $45 \%)$ dan 4 lama kontak (15 menit, 30 menit, 60 menit dan 120 menit). Replikasi dilakukan sebanyak dua kali. Bahan baku tanaman di peroleh dari kebun tanaman pagar yang ada di lingkungan tempat tinggal masyarakat Kota Bandar Lampung. Ekstraksi dilakukan di laboratorium Teknologi Hasil Pertanian Politeknik Pertanian Negeri Lampung.

Sebanyak 10 ekor lalat $M$. domestica (berumur 3-5 hari) yang berasal hasil pembiakan dimasukkan kedalam botol kaca berinsektisida selama masa kontak yang telah ditentukan yaitu 15 menit, 30 menit, 60 menit, dan 120 menit. Sebagai kontrol digunakan 10 ekor lalat yang dimasukkan ke dalam botol hanya diberi perlakuan dengan aquadest. Setelah dipaparkan sesuai waktu kontak, lalat dipindahkan ke kandang kasa $\left(25 \times 25 \times 25 \mathrm{~cm}^{3}\right)$. Lalat diberi pakan dan diamati jumlah lalat yang mati dalam 24 jam.

\section{HASIL}

Rerata mortalitas lalat rumah paling tinggi 
setelah dipaparkan ekstrak daun papaya yaitu sebesar 96,5\%. Diikuti paparan daun jambu biji sebanyak $87,25 \%$ dan daun delima $63,25 \%$.

Mortalitas terendah pada lalat yang dipaparkan daun delima $(63,25 \%)$. Tabel 1 menjelaskan adanya perbedaan kematian lalat berdasarkan konsentrasi tanaman. Pada ketiga jenis tanaman menunjukkan adanya perbedaan kematian.

Tabel 2 menunjukkan bahwa terdapat perbedaan kematian lalat pada daun delima dan daun jambu biji, sedangkan pada daun pepaya tidak menunjukkan adanya perbedaan.

Tabel 1. Perbedaan kematian Musca domestica berdasarkan konsentrasi ektrak tanaman

\begin{tabular}{lcccc}
\hline \multirow{2}{*}{ Tanaman } & \multicolumn{3}{c}{ Parameter } \\
\cline { 2 - 5 } & $N$ & Levene Tes & Nilai $F$ & P-value \\
\hline Daun Delima & 24 & 0,047 & 4,793 & 0,006 \\
Daun Pepaya & 24 & 0,008 & 167,521 & 0,000 \\
Daun Jambu Biji & 24 & 0,012 & 28,463 & 0,000 \\
\hline
\end{tabular}

Tabel 2. Perbedaan kematian Musca domestica berdasarkan lama kontak dengan ektrak tanaman

\begin{tabular}{lcccc}
\hline \multirow{2}{*}{ Tanaman } & \multicolumn{4}{c}{ Parameter } \\
\cline { 2 - 4 } & $N$ & Levene Tes & Nilai $F$ & P-value \\
\hline Daun Delima & 24 & 0,316 & 3,228 & 0,044 \\
Daun Pepaya & 24 & 1,000 & 0,075 & 0,973 \\
Daun Jambu Biji & 24 & 0,012 & 28,463 & 0,000 \\
\hline
\end{tabular}

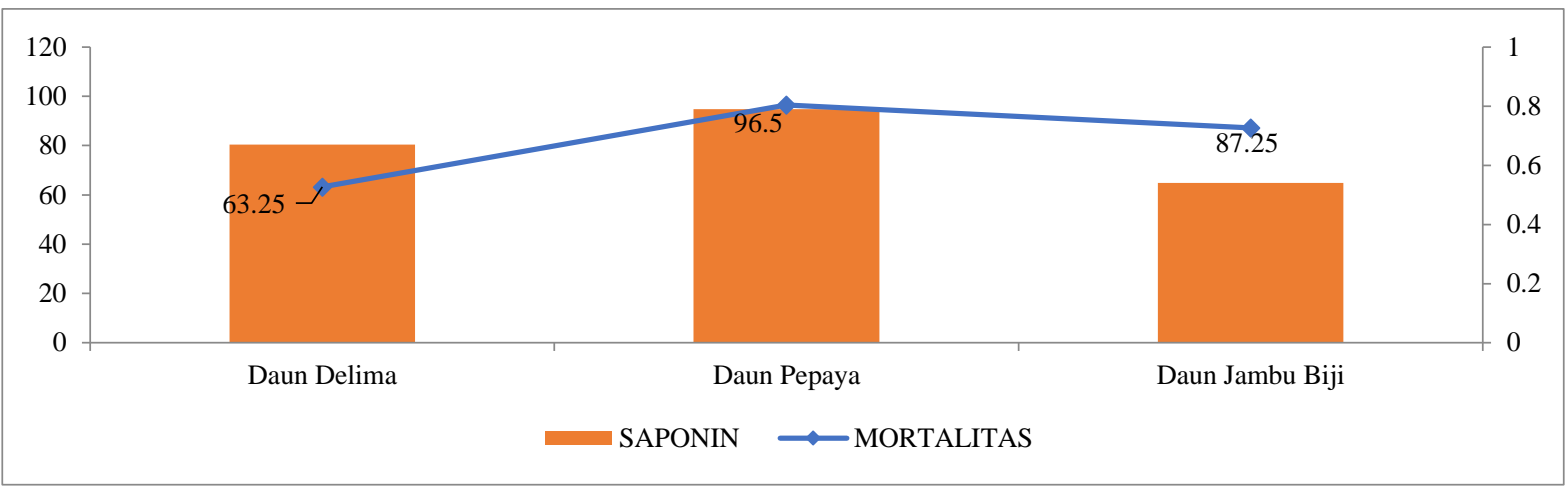

Gambar Mortalitas Musca domestica berdasarkan kandungan saponin pada tanaman

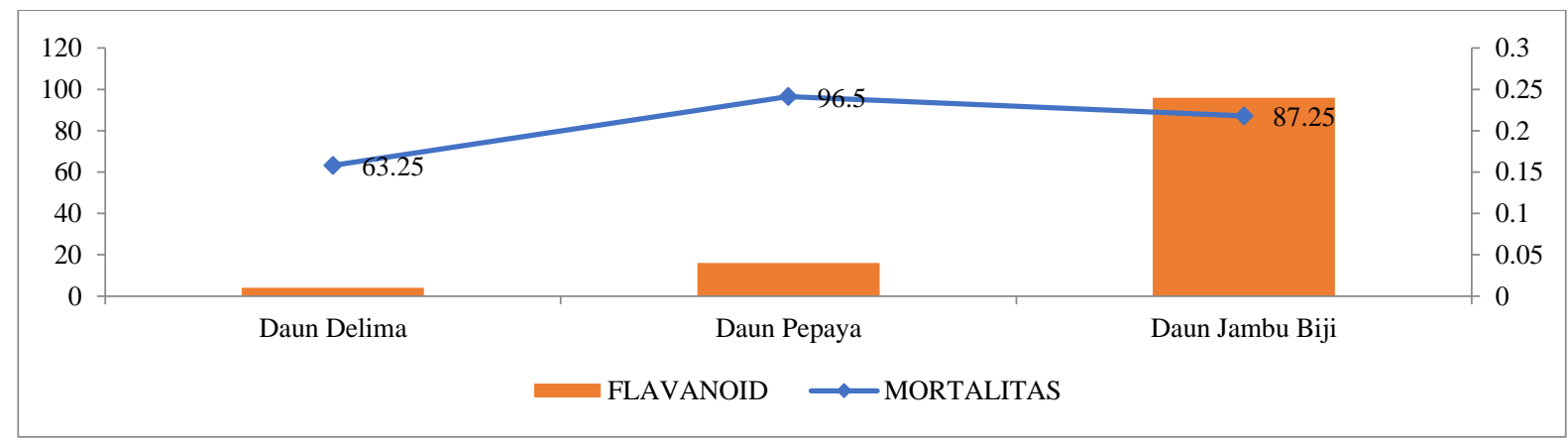

Gambar 2 Mortalitas Musca domestica berdasarkan kandungan flavonoid pada tanaman

Gambar 1 menerangkan kandungan saponin tertinggi pada daun pepaya dan kematian lalat yang tertinggi setelah dikontakkan dengan ekstrak daun pepaya. Pada gambar 2. kandungan flavonoid tertinggi pada ekstrak daun jambu biji. 


\section{PEMBAHASAN}

Pepaya memiliki potensi sebagai pengendali serangga karena kandungan zat racun yang dimilikinya. Adanya zat racun yaitu papain dalam daun pepaya bersifat racun bagi ulat dan hama penghisap ${ }^{(8)}$. Papain adalah enzim proteolitik yang dapat menyebabkan protein pecah dan terurai sehingga berpotensi sebagai pestisida ${ }^{(9)}$. Akan tetapi, pemanfaatan daun pepaya sebagai insektisida nabati untuk mengendalikan lalat belum dilakukan. Penelitian ini mendapatkan kemampuan daun papaya dalam membunuh lalat sebanyak 96,5\%. Hasil ini membuktikan bahwa daun papaya memiliki kemampuan yang sangat baik sebagai bioinsectisida dalam mengendalikan lalat. Uji kandungan bahan aktif dalam daun papaya menghasilkan sejumlah $79 \%$ saponin dan $4 \%$ flavonoid.

Hingga saat ini ditemukan penelitian tentang kemampuan daun delima sebagai bioinsectisida. Penelitian tentang daun delima dilatarbelakangi adanya kandungan alkaloid, resin, dan tannin sebagai bahan aktif yang terkandung didalam kulit Buah Delima (10). Meski jumlah kematian lalat setelah dipaparkan ekstrak daun delima hanya $63,25 \%$, tidak sebesar daun papaya dan daun jambu biji (96,5\% dan $87,5 \%$ ). Tetapi daun delima perlu diperhitungkan sebagai bioinsectisida yang mudah diperoleh di lingkungan tempat tinggal. Pada daun delima terdapat $67 \%$ saponin dan $4 \%$ flavonoid. Sedangkan pada daun jambu biji terdapat 54\% saponin dan $24 \%$ flavonoid.

Kematian lalat disebabkan karena perbedaan konsentrasi ektrak yang dipaparkan terhadap lalat. Semakin besar konsentrasi, semakin banyak kandungan rancun didalamnya. Hal ini dibuktikan dengan semakin tinggi saponin diikuti dengan kematian lalat yang tinggi. Keberadaan flavonoid dalam tanaman menambah kemampuan tanaman dalam mengendalikan lalat. Hasil ini sejalan dengan penelitian lain yang menyatakan bahwa konsentrasi berpengaruh terhadap kematian serangga ${ }^{(10,11)}$.

Flavonoid sebagai metabolit sekunder yang berperan sebagai hormon juvenile. Hormon ini menyebabkan telur lalat tidak dapat menetas. Adanya flavonoid mengganggu aktivitas system kerja syaraf melalui saluran pernafasan lalat ${ }^{(12)}$. Saponin bertindak sebagai racun perut. Rasanya yang pahit, jika dimakan oleh serangga akan menyebabkan iritasi lambung. Saponin juga memiliki sifat menyerupai detergen. Sifat ini berdampak pada tegangan permukaan kulit serangga akan rusak sehingga senyawa racun masuk kedalam tubu serangga (13). Senyawa saponin juga dapat mematikan serangga karena mampu menyebabkan hemolisis sel-sel darah merah ${ }^{(14)}$.

\section{KESIMPULAN DAN SARAN}

Daun pepaya memiliki kandungan racun yang paling tinggi dibanding delima dan daun jambu biji. Ektrak daun papaya efektif digunakan sebagai bioinsectisida yang ramah lingkungan dalam mengendalikan lalat rumah.

\section{UCAPAN TERIMA KASIH}

Ucapan terima kasih disampaikan kepada Direktur Politeknik Kesehatan Tanjungkarang, dan kepala pusat penelitian dan pengabdian masyarakat yang memberikan dukungannya sehingga terlaksana penelitian ini.

\section{DAFTAR PUSTAKA}

1. Kementerian Kesehatan RI. Laporan Nasional Riset Kesehatan Dasar. Riskesdas. Jakarta: Badan Penelitian dan Pengembangan Kesehatan, Kemenkes RI; 2018. p. 614.

2. Pusat Data dan Informasi Kemenkes RI. Profil Kesehatan Indonesia Tahun 2018. Kurniawan R, Yudianto Y, Hardana B, Siswanti T, editors. Jakarta: Kementrian Kesehatan RI; 2019.

3. Laseri TE. Hubungan Hygiene Sanitasi dan Perilaku Penjamah Makanan dengan Akngka Kuman pada Makanan Jajanan di Lingkungan Sekolah Yayasan Kartika Jaya Kota Bandar Lampung. Politeknik Kesehatan Kemenkes Tanjungkarang; 2017.

4. Izati A, Saputri DA, Kamelia M, Widiani N. Analisis Faktor Yang Berhubungan Dengan Kejadian Diare Pada Balita Di Puskesmas Kedaton Kota Bandar Lampung. J Ilmu Kedokt dan Kesehat. 2020;7(2):1-7.

5. Suyono, Budiman. Ilmu Kesehatan Masyarakat dalam Konteks Kesehatan Lingkungan. Jakarta: EGC; 2011.

6. Sari WR, Muryoto M, Kadarusno AH. Minyak Kenanga (Canangium odoratum Baill) Sebagai Repellent Llat Rumah (Musca domestica). Sanitasi J Kesehat Lingkung. 2017;8(2):57.

7. Fathonah A. Uji Toksisitas Ektrak Daun dan Biji Cariya Papaya sebagai Larvasida 
Anopheles aconitus. Yogyakarta: Program Studi Biologi Fakultas Sain dan Teknologi Universitas Islam Negeri Sunan Kalijaga Yogyakarta; 2013.

8. Julaily N, Mukarlina, Setyawati TR. Pengendalian Hama pada Tanaman Sawi (Brassica juncea L.) Menggunakan Ekstrak Daun Pepaya (Carica papaya L.). J Protobiont. 2013;2(3):171-5.

9. Harrison RL, Bonning BC. Proteases as insecticidal agents. Toxins (Basel). 2010;2(5):935-53.

10. Binawati DK, Amilah S. Pengaruh Ekstrak Kulit Delima (Punica granatum) dan Rumput Teki (Cyperus rotundus) terhadap Mortalitas Larva Nyamuk Aedes aegypti. Wahana. 2014;2(1):21-5.

11. Balitsa PT, Pembuatannya D a NC. Untuk Pengendalian Organisme Pengganggu Tumbuhan ( Opt ).

12. Satiyarti RB, Yana Y, Fatimatuzzahra F. Penggunaan Ekstrak Daun Jambu Biji (Psidium guajava L.) sebagai Ovisida Keong Mas (Pomacea canaliculata L.). al-Kimiya. 2019;6(1):32-5.

13. Purwatiningsih P, Mandasari FP, Fajariyah S. Toksisitas Ekstrak n-heksana Serbuk Gergaji Kayu Sengon (Albizia falcataria 1. Forberg) terhadap Mortalitas Serangga Penggerek Buah Kopi (Hypothenemus hampei ferr.) (Scolytidae: Coleoptera). Biotropic J Trop Biol. 2019;3(1):39-48.

14. Chaieb I. Saponins as Insecticides: a Review. Tunis J Plant Prot 5. 2010;5(1):3950. 